\title{
ANALISA PENGARUH DEBIT AIR LIMPASAN CURAH HUJAN DI DAS KABUPATEN OGAN KOMERING ILIR TERHADAP JUMLAH TITIK PANAS/TITIK HOTSPOT PADA BULAN JUNI - NOVEMBER 2014
}

\author{
Rini. M Sibarani, M. Bayu Prayoga, Alfan Muttaqin
}

\begin{abstract}
INTISARI
Titik panas / titk Hotspot merupakan indikator kebakaran lahan dan hutan yang selalu menjadi masalah pada saat kondisi udara kering. Rendahnya intensitas curah hujan di suatu wilayah mengakibatkan jumlah titik panas ini meningkat. Hal ini dapat dilihat dari jumlah debit limpasan curah hujan di suatu wilayah. Pada tahun 2014 di Kabupaten Ogan Komering llir terditeksi jumlah titik panas terbanyak. Dimana ada 4 Daerah Aliran Sungai dengan luasan daerah yang cukup besar. Daerah aliran ini mengalami jumlah titik panas terbanyak pada bulan September hingga dasarian kedua bulan November 2014. Selain disebabkan karena debit limpasan dan intensitas curah hujan, jenis lahan dan kelembapan udara juga menjadi faktor penyebab pertambahan jumlah titik panas.
\end{abstract}

\begin{abstract}
ABSTRAC
Hotspot is an indicator of land and forest fires which were always a problem when the dry air conditions. The low intensity of rainfall in the region resulted in the number of hotspots is increasing. It can be seen from the amount of runoff discharge rainfall in a region. In 2014 in Ogan Ogan llir detected a fairly high the amount of hotspots. Where there are 4 Watershed with an area large enough. In This flow area detected a fairly high the amount of hotspots in September until second dasarian November 2014. In addition due to the discharge of runoff and the intensity of rainfall, type of soil and the humidity also become a factor increasing hotspots.
\end{abstract}

Kata Kunci : titik hotspot, kebakaran lahan, debit limpasan

\section{PENDAHULUAN}

Indonesia dengan luas daratan sekitar 188,2 juta ha, terdiri dari lahan kering dan lahan rawa. Lahan gambut terluas di Indonesia terdapat di pulau Sumatera, yaitu 6.436.649 hektar dengan luasan berimbang antara kedalaman dangkal (50$100 \mathrm{~cm}$ ) sampai sangat dalam $(>300 \mathrm{~cm})$. Sebaran lahan gambut terluas di Sumatera terdapat di Provinsi Riau, kemudian Sumatera Selatan dan Jambi. Sedangkan provinsilainnya $<262.000$ hektar. Provinsi Sumatera Selatan merupakan daerah yang memiliki lahan gambut terluas kedua di pulau Sumatera, dengan sebaran gambut berada di Kabupaten Ogan Komering Ilir (500.000 ha), Muba (250.000ha), Banyuasin (200.000ha), Muara Enim (45.000 ha) dan Musi Rawas (35.000 ha).

Daerah gambut pada umumnya berupa rawarawa, dimana pada bagian atas lahan gambut biasanya terdapat tanaman hidup sehingga bagian atas lahan gambut tersebut banyak mengandung akar-akar kecil tumbuhan. (Notohadiprawiro, 1988).Dalam keadaan yang kering tanah gambut sangat kering, berat isi tanah organik dibandingkan dengan tanah mineral sangat rendah yaitu $0.2-0.3 \mathrm{kN} / \mathrm{m}^{3}$ yang merupakan nilai umum bagi tanah organik yang telah mengalami dekomposisi lanjut sedangkan berat isi kering untuk tanah mineral 1.25 $1.45 \mathrm{kN} / \mathrm{m}^{3}$. Gambut juga mempunyai sifat menyerap air yang tinggi tanah mineral kering dapat menahan air 1/5 - 1/2 dari bobotnya sedangkan tanah gambut dapat menahan 2-4 kali bobot keringnya. (Notohadiprawiro, 1988),

Karakteristik fisik lahan gambut meliputi kadar air, berat isi (bulk density, BD), daya menahan beban (bearing capacity), subsiden (penurunan permukaan), dan mengering tidak balik (irriversible drying). Salah satu sifat atau karakteristik gambut yang harus kita perhatikan pada saat kondisi cuaca kering adalah kadar air serta kapasitas memegang air. Kadar air tanah gambut berkisar antara $100-1.300 \%$ dari berat keringnya(13 kali bobotnya) menyebabkan BD menjadi rendah. Bulk density terkait dengan tingkat kematangan dan kandungan bahan mineral, dimana semakin matang dan semakin tinggi kandungan bahan mineral maka BD akan semakin besar dan tanah gambut semakin stabil (tidak mudah mengalami kerusakan). Sajarwan (2007) mengemukakan bahwa terjadi penurunan nilai BD dari pinggir sungai ke arah kubah gambut. Karena karatkteristik kadar air lahan gambut sangat tinggi, maka pada saat kondisi 
udara kering lahan gambut juga kering dan dengan sendirinya lebih sensitif terhadap temperatur udara yang tinggi sehingga lebih mudah terbakar. Hal tersebut dapat kita lihat dari data sebaran titik hotspot tahun 2014, dimana terlihat banyak sebaran titik hotspot pada bulan Juni-September 2014 di daerah Sumatera Selatan khususnya di Kabupaten Ogan Komering Ilir (OKI).

\section{Kabupaten Ogan Komering Ilir}

Salah satu kabupaten yang memiliki luas gambut terbesar di Sumatera Selatan adalah Ogan Komering llir. Kabupaten yang sering disingkat OKI ini beribukotakan Kayu Agung, merupakan Kabupaten yang memiliki luas 19.023,47 $\mathrm{Km}^{2}$ dan berpenduduk sekitar 700.000 jiwa. Seperti peta administrasi Kabupaten OKI pada gambar 1, dijelaskan bahwa wilayah ini memiliki 14 Kecamatan, yang terdiri atas 299 Desa/Kelurahan. Wilayah Kabupaten Ogan Komering ilir terletak di bagian Timur Provinsi Sumatera Selatan yaitu tepatnya antara $104^{\circ} 20^{\prime}$ dan $106^{\circ} 00^{\prime}$ Bujur Timur dan $2^{\circ} 30^{\prime}$ sampai $4^{\circ} 15^{\prime}$ Lintang Selatan, luasnya mencapai 19.023,47 $\mathrm{Km}^{2}$.

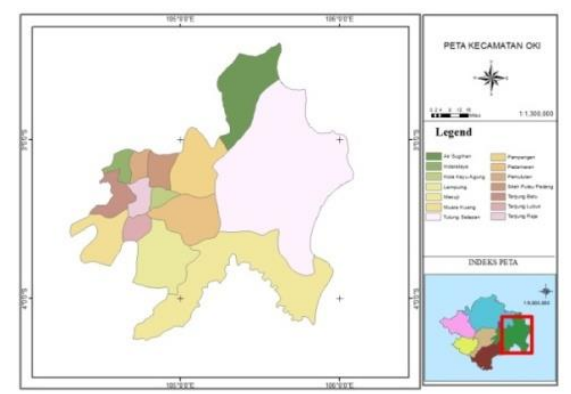

Gambar 1. Peta Administrasi Kabupaten Ogan Komering Ilir

Sekitar 75 persen dari luas wilayah Kabupaten OKI merupakan bentangan rawa dan 25 persennya merupakan daratan. Daerah ini dialiri oleh banyak sungai dan memiliki wilayah pantai dan laut. Wilayah pesisir Pantai Timur OKI meliputi Kecamatan Air Sugihan, Tulung Selapan, Cengal dan Kecamatan Sungai Menang. Kabupaten OKI secara fisiografis terletak pada bentang alam dataran rendah yang menempati sepanjang Sumatera bagian timur. Wilayah ini sebagian besar memperlihatkan tipologi ekologi rawa, meskipun secara lokal dapat ditemukan dataran kering. Dengan demikian wilayah OKI dapat dibedakan menjadi dataran lahan basah dengan topografi rendah (lowland) dan dataran lahan kering yang memperlihatkan topografi lebih tinggi (Upland). Daerah lahan basah hampir meliputi $75 \%$ wilayah OKI dan dapat dijumpai di kawasan sebelah timur seperti Kecamatan Air Sugihan, Tulung Selapan, Cengal, dan Kecamatan Sungai Menang. Sedangkan lahan kering dapat ditemukan pada wilayah/daerah dengan topografi bergelombang,yaitu di Kecamatan Mesuji Makmur, Lempuing dan Kecamatan Lempuing Jaya.

Wilayah barat Kabupaten Ogan Komering llir berupa hamparan dataran rendah yang sangat luas. Sebagian besar 25 persen daratan dan 75 persen perairan yang merupakan rawa-rawa yang membentang. Beberapa kecamatan dialiri sungaisungai yang berfungsi sebagai jalur transportasi air. Daerah pegunungan hampir tidak ada, hanya terdapat daratan sempit dan daerah yang berbukitbukit di Kecamatan Pampangan. Daerah yang paling rendah adalah Kecamatan Air Sugihan dengan ketinggian hanya 8 meter dari permulaan laut, sedangkan yang tertinggi adalah di Kecamatan Mesuji Makmur. Di sisi Timur terdapat garis pantai yang memanjang dari kecamatan Sungai Menang, Cengal, Tulung selapan dan Kecamtan Air Sugihan. Garis pantai tersebut bermuara pada Laut selat Bangka.

Sistem hidrologi yang membentuk danau di wilayah OKI pada prinsipnya termasuk ke dalam satuan geomorfik rawa, karena air yang terakumulasi di dalam cekungan tersebut pada umumnya berasal dari rawa yang berada di sekitarnya. Kabupaten in ada empat danau yaitu danau Deling di Kecamatan Pampangan, danau Air Nilang di Kecamatan Pedamaran, danau Teluk Gelam di Kecamatan Teluk Gelam dan danau Teloko di Kecamatan Kayuagung. Sedangkan Daerah Aliran Sungai (DAS) di Kabupaten OKI memiliki 3 sistem yaitu DAS Musi, DAS Bulularinding dan DAS Mesuji. DAS (Watershed) atau dalam skala luasan kecil disebut Catchment Area adalah suatu wilayah daratan yang dibatasi oleh punggung bukit atau batas-batas pemisah topografi, yang berfungsi menerima, menyimpan dan mengalirkan curah hujan yang jatuh di atasnya ke alur-alur sungai dan terus mengalir ke anak sungai dan ke sungai utama, akhirnya bermuara ke danau/waduk atau ke laut. Di daerah aliran sungai banyak terdapat lebak yang pasang surut airnya dipengaruhi oleh musim(http://go.kaboki.go.id/ profil/geografi-kabupaten-oki). Ada 11 Daerah Aliran Sungai yang tersebar di wilayah Kabupaten OKI yang dapat dilihat pada gambar 2 berikut :



Gambar 2. Peta Administrasi Kabupaten Ogan Komering llir Peta Daerah Aliran Sungai Kabupaten OKI

Sebagian besar wilayah di kabupaten OKI terutama di kota Kayu Agung tergolong tropik basah dengan curah hujan rerata Tahunan > 
$2.500 \mathrm{~mm} / \mathrm{tahun}$ dan jumlah hari hujan dan hari hujan rata-rata $>116$ hari/tahun. Musim Kemarau umumnya berkisar antara bulan Mei sampai Oktober setiap tahunnya, sedangkan musim penghujan berkisar antara bulan November sampai Bulan April. Penyimpangan musim biasanya terjadi dalam lima tahun, berupa musim penghujan, dengan rata-rata curah hujan lebih kurang $1.000 \mathrm{~mm} /$ tahun dengan rata-rata hari hujan 60 hari/tahun (https://id.wikipedia.org/wiki/ Kabupaten_Ogan_Komering_llir).

\section{DATA DAN METODELOGI}

Dalam pembahasan paper ini digunakan metodelogi sebagai berikut ;

\section{Pengumpulan data}

Data yang digunakan adalah data skunder tahun 2014, yaitu data yang diperoleh dengan mendownload dari satelit. Adapun data yang digunakan adalah data curah hujan yang diambil dari satelit TRMM dan data sebaran titik panas atau titik hotspot yang didapat dari satelit NOAA-18.

2. Pengolahan data

Data-data yang telah diperoleh diolah dengan menggunakan analisa matematis, yang akan disajikan dalam bentuk data visual, grafik dan tabel. Pengolahan data yang dilakukan pada tulisan ini adalah menghitung curah hujan, menghitung jumlah hotspot dan menghitung debit aliran curah hujan yang nantinya dapat digunakan untuk menentukan besaran air minimal yang dibutuhkan lahan untuk mengurangi jumlah hotspot di wilayah Kabupaten OKI.

\subsection{Menghitung Curah Hujan}

Hujan adalah sebuah proses kondensasi uap air di atmosfer menjadi butir air yang cukup berat untuk jatuh dan biasanya tiba di permukaan. Hujan biasanya terjadi karena pendinginan suhu udara atau penambahan uap air ke udara. Curah hujan adalah jumlah air yang jatuh di permukaan tanah datar selama periode tertentu yang diukur dengan satuan tinggi milimeter $(\mathrm{mm})$ di atas permukaan horizontal, atau dapat juga dikatakan bahwa curah hujan merupakan ketinggian air hujan yang terkumpul dalam tempat yang datar, tidak menguap, tidak meresap dan tidak mengalir. Curah hujan $1 \mathrm{~mm}$ adalah jumlah air hujan yang jatuh di permukaan per satuan luas ( $\mathrm{m} 2$ ) dengan catatan tidak ada yang menguap, meresap atau mengalir. Jadi, curah hujan sebesar $1 \mathrm{~mm}$ setara dengan 1 liter/ m2 . (Aldrian. E, 2011)

Intensitas hujan adalah banyaknya curah hujan per satuan jangka waktu tertentu. Apabila dikatakan intensitas besar, berarti hujan lebat dan ini kurang baik bagi tanaman dan peternakan, karena dapat menimbulkan erosi dan banjir. (Kertasapoetra, A. G, 2008). Jenis-jenis hujan berdasarkan besarnya intensitas curah hujan menurut BMKG dibagi manjadi tiga, yaitu : hujan sedang, $20-50 \mathrm{~mm}$ per hari, hujan lebat, 50-100 $\mathrm{mm}$ per hari, dan hujan sangat lebat, di atas 100 $\mathrm{mm}$ per hari.

Data Curah hujan dapat diperoleh dari beberapa alat pengukur curah hujan, baik yang sederhana maupun yang kompleks. Alat pengukur curah hujan sederhana atau manual menggunakan prinsip pembagian antara volume air hujan yang ditampung lalu dibagi luas penampang/mulut penakar. Alat pengukur kompleks yaitu alat pengukur curah hujan otomatis menggunakan prinsip pelampung, timbangan dan jungkitan. Contoh alat pengukur yang terdapat saat ini yaitu Hellman dan Tipping-bucket gauge. Curah hujan suatu wilayah dapat kita ukur, jika pada terpasang alat pengukur curah hujan di wilayah tersebut atau yang disebut penakar hujan.

Cara lainnya mengukur curah hujan suatu wilayah tanpa menggunakan penakar curah hujan adalah dengan memanfaatkan data dari satelit TRMM (Tropical Rainfall Measuring Mission). TRMM adalah salah satu citra penginderaan jauh yang digunakan untuk memantau curah hujan di daerah tropis seperti Indonesia. data precipitasi (hujan) yang didapat dari satelit meteorologi TRMM (Tropical Rainfall Measuring Mission) dengan sensornya PR (Precipitation Radar), TMI (TRMM Microwave Imager), dan VIRS (Visible and Infrared Scanner), CERES (Clouds and the Earth's Radiant Energy System), dan LIS (Lightning Imaging Sensor).

Pada paper kali ini data curah hujan yang digunakan adalah data curah hujan 6 bulan yang telah di download dari satelit TRMM Jaxa dari bulan Juni sampai dengan November 2014, yang kemudian dijalankan dengan menggunakan program Grads. Berikut data curah hujan spasial untuk wilah kabupaten Ogan Komering llir yang diambil dari data TRMM. Data tersebut merupakan data curah hujan dengan intensitas terendah dan tertinggi tiap bulannya. Dari data spasial di bawah, terlihat intensitas curah hujan di wilayah OKI dan sekitarnya sangat kecil pada bulan AgustusOktober 2014, sedangkan bulan Juni,Juli, September, dan November 2014 masih terjadi curah hujan dengan intensitas sedang hingga tinggi.

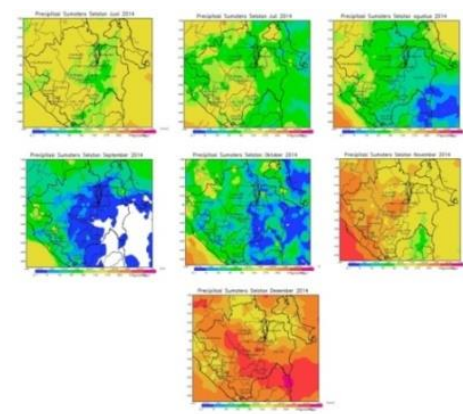

Gambar 3. Curah hujan Daerah OKI JuniDesember 2014 (trmm/jaxa) 


\subsection{Menghitung Titik panas / Titik Hotspot}

Titik panas atau titik hotspot adalah ilndikator kebakaran lahan dan hutan yang mendeteksi suatu lokasi yang memiliki suhu relatif tinggi dibandingkan suhu disekitarnya". (Pasal 1 angka 9 Permenhut No. P 12/ PMenhut-II/ 2009).Titik panas atau titik hotspot merupakan indikator yang terjadinya kebakaran lahan atau hutan di suatu wilayah. Titik panas atau titik hotspot di suatu wilayah akan terpantau satelit, yang kemudian akan diinformasikan dalam bentuk data titik hotspot beserta dengan lokasinya. Ada beberapa satelit yang dapat menangkap titik api atau titik hotspot di suatu wilayah, antaralain satelit Modis Terra dan Aqua serta satelit NOAA-18.

Data yang digunakan dalam paper ini adalah data titik panas/titik hotspot harian dari satelit NOAA-18. Dari data spasial maupun hitungan yang ada terlihat bahwa pada tahun 2014, titik panas terbesar di provinsi Sumatera Selatan terdapat di wilayah Kabupaten OKI. Hal ini berkaitan dengan lahan gambut yang ada di wilayah tersebut, seperti yang telah dijelaskan pada bagian pendahuluan. Karena wilayah ini memiliki sebaran lahan gambut terluas, maka pada musim kering wilayah ini lebih memiliki tingkat kerawanan untuk terbakar yang cukup tinggi. Dari data sebaran titik panas / titik hotspot di bawah ini, terlihat jelas adanya peningkatan titik panas / titik hotspot yang cukup tinggi di wilayah Sumatera Selatan khusunya di Kabupaten OKI pada kondisi kering, yaitu bulan September November 2014.

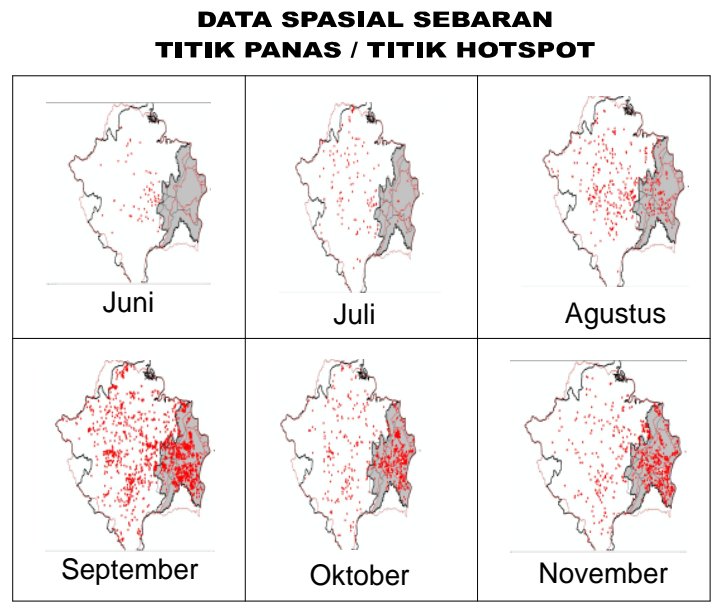

Gambar 4. Sebaran Titik Panas / Titik Hotspot Daerah OKI Juni-November 2014 (trmm/jaxa)

\subsection{Menghitung Debit Air Limpasan Curah hujan di DAS}

Daerah aliran Sungai (DAS) atau Catchment Area adalah suatu wilayah daratan yang dibatasi oleh punggung bukit atau batas- batas pemisah topografi, yang berfungsi menerima, menyimpan dan mengalirkan curah hujan yang jatuh di atasnya ke alur-alur sungai dan terus mengalir ke anak sungai dan ke sungai utama. Sebagian besar wilayah di daerah Kabupaten OKI merupakan daerah aliran sungai. Jika dilihat dari data topografinya, ada 11 DAS di wilayah Kabupaten OKI. Daerah aliran sungai Musi merupakan DAS terluas di wilayah Sumatera Selatan. Sepertiga luas DASnya merupakan bagian dari Kabupaten OKI. Sebagian besar kecamatannya menjadi bagian daerah aliran sungai tersebut. Sedangkan Teluk Puleh merupakan daerah aliran Sungai dengan luas wilayah terkecil.

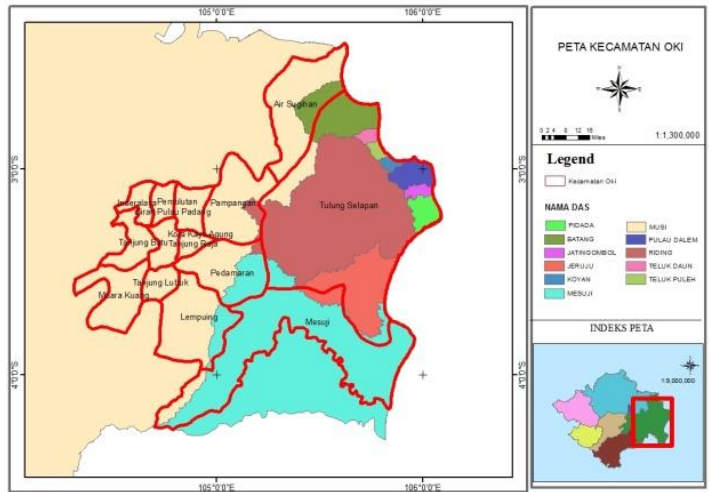

Gambar 5. Peta Kecamatan di daerah Kabupaten OKI

Tulisan ini akan menggunakan DAS sebagai Catchment Area atau sebagai daerah tangkapan air hujan yang nantinya akan mengalirkan air hujan tersebut menuju kesaluran. Adapun luas 11 DAS (Daerah aliran Sungai) atau Catchment Area yang ada di daerah OKI dapat dilihat pada tabel di bawah :

\begin{tabular}{|l|c|r|}
\hline $\begin{array}{c}\text { DAS (Daerah Aliran } \\
\text { Sungai) }\end{array}$ & Luas (acre) & Luas (ha) \\
\hline musi & $1,986,210.00$ & $794,484.00$ \\
\hline Batang & $232,259.70$ & $92,903.88$ \\
\hline tlk_daun & $18,501.34$ & $7,400.53$ \\
\hline tlk_puleh & $16,825.19$ & $6,730.08$ \\
\hline Koyan & $15,399.80$ & $6,159.92$ \\
\hline Pulau dalam & $71,766.82$ & $28,706.73$ \\
\hline Jatingombol & $21,935.92$ & $8,774.37$ \\
\hline Riding & $1,071,589.36$ & $428,635.74$ \\
\hline jeruju & $315,145.79$ & $126,058.32$ \\
\hline mesuji & $1,139,524.00$ & $455,809.60$ \\
\hline Pidada & $65,886.75$ & $26,354.70$ \\
\hline Tabel 1. Luas Daerah Aliran Sungai di \\
\hline \multicolumn{2}{|c|}{ Kabupaten OKI } \\
\hline
\end{tabular}

Debit air limpasan adalah volume air hujan per satuan waktu yang tidak mengalami infiltrasi sehingga harus dialirkan melalui saluran drainase. Debit air limpasan terdiri dari tiga komponen yaitu Koefisien Run Off ( C ), Data Intensitas Curah Hujan (I), dan Catchment Area (Aca). Sehingga 
debit air limpasan dapat dihitung dengan menggunakan persamaan berikut :

$$
Q_{\text {limpasan }}=0,277 \times C \times I \times A \ldots \ldots \text { (i) }
$$

Koefisien limpasan (run off) merupakan koefisien yang besarnya tergantung pada kondisi permukaan tanah, kemiringan medan, jenis tanah, dan lamanya hujan di daerah pengaliran. Koefisien ini dapat ditentukan dengan menggunakan persamaan berikut :

$$
C=\frac{C_{1} \times A_{1}+C_{2} \times A_{2}+\cdots+C_{n} \times A_{n}}{A_{1}+A_{2}+\cdots+A_{n}}
$$

Sebagian besar wilayah OKI memiliki topografi datar hingga landai dengan kemiringan < $\mathbf{2 \%}$, sebagian lainnya seperti di wilayah Kecamatan Mesuji dan Kecamatan Lempuing Jaya memiliki topografi bergelombang dengan kemiringan 2 - 15\% . Wilayah yang sering mengalami titik panas / titik hotspot adalah rawa, semak-semak dan lahan terbuka. Sehingga dalam tulisan kali ini, koefisien limpasan yang digunakan dalam mencari debit air di setiap DAS sebesar 0,7. Dimana nilai C (koefisien limpasan) ini nilainya berbeda-beda untuk setiap jenis lahan, untuk lebih jelas dapat dilihat pada tabel berikut :

\begin{tabular}{|llr}
\multicolumn{2}{c}{ Tabel 3.1. Koefisien Limpasan (C.W. Fetter, 2000) } \\
\hline Kemiringan & \multicolumn{1}{c}{ Jenis lahan } & C \\
$<3 \%$ (datar) & Sawah, rawa & 0,2 \\
& Hutan, perkebunan & 0,3 \\
\multirow{3}{*}{$3 \%-15 \%$ (sedang) } & Perumahan & 0,4 \\
& Hutan, perkebunan & 0,4 \\
& Perumahan & 0,5 \\
& semak-semak agak jarang & 0,6 \\
$>15 \%$ (curam) & Lahan terbuka & 0,7 \\
& Hutan & 0,6 \\
& Perumahan & 0,7 \\
& Semak-semak agak jarang & 0,8 \\
& Lahan ternuka daerah tambang & 0,9 \\
\hline
\end{tabular}

Tabel 2. Koefisien Limpasan (Run Off) (C.W. Fetter)

Data debit air limpasan curah hujan ini akan menjadi tolak ukur dalam menganalisa pengaruh debit air limpasan DAS di Kab. OKI terhadap jumlah titik panas/titik hotspot pada kondisi kering, yaitu Juni - November 2014.

\section{HASIL DAN PEMBAHASAN}

Seperti yang diketahui, bahwa pada kondisi kering, lahan gambut relatif mudah terbakar. Hal ini menyebabkan titik panas akan meningkat. Dari data yang di peroleh terlihat jumlah titik panas yang cukup tinggi pada bulan September hingga November awal. Jika diurutkan dari jumlah titik panas terbanyak, maka ada kurang lebih 4 DAS di daerah OKI yang lahannya sangat rentan terbakar, diantaranya : DAS Musi, DAS Riding, DAS, Jeruju dan dan Mesuji. Pada bulan September lebih banyak titik panas di wilayah Kabupaten Ogan Komering Ilir, terutama di Ridng, Mesuji dan Musi.

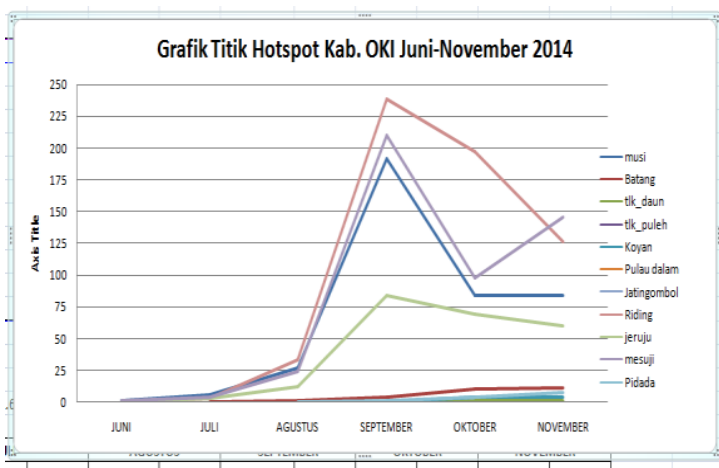

Gambar 6. Jumlah Hotspot di Kab. OKI Juni- November 2014 (NOAA18)

Jika dilihat dari data curah hujan di ketiga DAS tersebut tidaklah berbeda dengan DAS lainnya. Pada bulan September Kondisi udara kering, sehingga intensitas curah hujan juga kecil. Data grafik di bawah ini menunjukkan intensitas curah hujan yang rendah pada bulan September. Hampir semua DAS tidak mengalami hujan. Ada beberapa hari pada bulan September, turun hujan dengan intensitas kecil di sebagian kecil DAS. Dari data terlihat intensitas curah hujan tertinggi pada bulan September terukur $4 \mathrm{~mm}$.

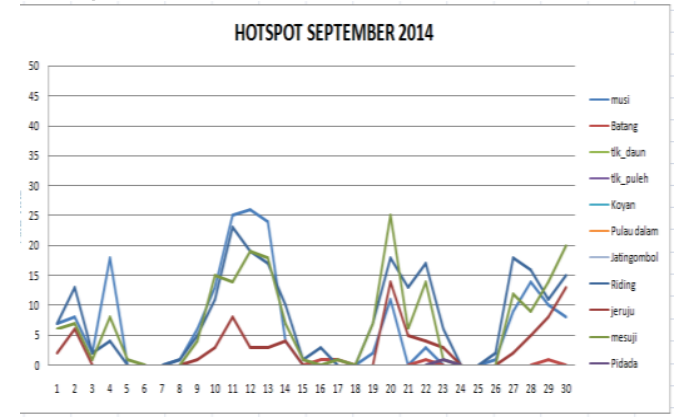

Gambar 7. Jumlah Curah Hujan September 2014 di Kab. OKI (TRMM-Jaxa)

Debit air limpasan di suatu daerah bergantung pada intensitas curah hujan dan luasan suatu wilayah. Untuk daerah Ogan Komering Ilir yang memiliki 11 Daerah Aliran Sungai ini, pada bulan Juni - November dapat dilihat pada grafik di bawah. Terlihat debit air limpasan hujan untuk DAS Musi selalu lebih tinggi disusul DAS Riding dan Mesuji. Dari grafik tersebut juga menunjukkan penurunan nilai debit air limpasan hujan pada bulan September dan Oktober 2014. Jika dilihat secara keseluruhan dan dibandingkan dengan grafik titik panas pada gambar sebelumnya terlihat bahwa debit limpasan air hujan berbanding terbalik dengan jumlah titik panas.

Berdasarkan jumlah titik panas terbanyak, maka diambil data debit limpasan untuk 4 DAS daerah Kab. OKI, yaitu: Musi, Riding, Jeruju dan Musi. untuk analisa pengaruh debit limpasan hujan terhadap jumlah titik panas. Jika dilihat dari luas 
wilayahnya, DAS tersebut memiliki luasan terbesar, sehingga debit limpasan curah hujan di wilayah tersebut tinggi jika intensitas curah hujan tinggi dan sebaliknya. Gambar berikut menampilkan jumlah curah hujan di DAS Kabupaten OKI.

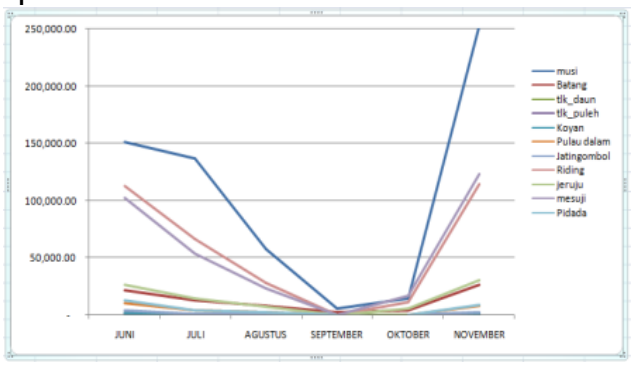

Gambar 8. Debit Air Limpasan Curah Hujan di Kab. OKI Juni- November 2014 (TRMM-Jaxa)

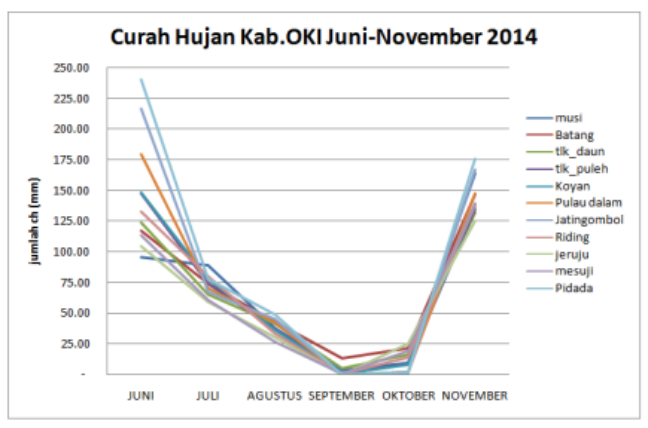

Gambar 9. Jumlah Curah Hujan Juni - November 2014 di Kab. OKI (TRMM-Jaxa)

Dari data grafik di atas, terlihat pada bulan september dan Oktober, Jumlah curah hujan di DAS Musi, Riding, Jeruju dan Mesuji rendah. Hal ini mempengaruhi debit limpasan dan jumlah titik panas di DAS tersebut. Sebagai contoh DAS Musi yang memiliki total hujan pada bulan September 3,47 $\mathrm{mm}$ harus membasahi wilayahnya dengan luasan 7,944.84 km. Dari persamaan (i) diperoleh debit limpasan pada bulan September sebesar $5,347.60 \mathrm{~m}^{3} /$ detik. Nilai ini dapat dikatakan debit limpasan tertinggi dibandingkan dengan DAS lainnya. Akan tetapi pada bulan September jumlah titik panas di DAS Musi terbesar urutan ke-tiga.

\begin{tabular}{|c|c|c|c|c|c|}
\hline \multicolumn{2}{|r|}{ DAS } & musi & Riding & ierviu & messui \\
\hline \multirow{2}{*}{ JUNI } & $\begin{array}{c}\text { JUMLAH DEBIT } \\
\left(\mathrm{m}^{3} / \mathrm{s}\right)\end{array}$ & $150,902.94$ & $112,898.94$ & $26,253.79$ & $102,775.50$ \\
\hline & \begin{tabular}{|l} 
JUMLAH HOTSPOT \\
\end{tabular} & 1.00 & - & - & 1.00 \\
\hline \multirow{2}{*}{ JUL } & $\begin{array}{c}\text { JUMLAA DEBIT } \\
\left(\mathrm{m}^{3} / \mathrm{s}\right)\end{array}$ & $136,901.35$ & $66,658.12$ & $14,394.66$ & $53,709.63$ \\
\hline & \begin{tabular}{|l} 
JUMLAH HOTSPOT \\
\end{tabular} & 6.00 & 3.00 & 3.00 & 4.00 \\
\hline \multirow{2}{*}{ tGustus } & $\begin{array}{l}\text { JUMLAH DEBIT } \\
\left(\mathrm{m}^{3} / \mathrm{s}\right)\end{array}$ & $57,981.16$ & $27,858.10$ & $7,430,62$ & $23,189.04$ \\
\hline & \begin{tabular}{|l} 
JUMLAH HOTSPOT \\
\end{tabular} & 27.00 & 33.00 & 12.00 & 24.00 \\
\hline \multirow{2}{*}{ :PTEMBER } & $\begin{array}{c}\text { JUMLAH DEBIT } \\
\left(\mathrm{m}^{3} / \mathrm{s}\right)\end{array}$ & $5,347.60$ & 539.20 & 18.20 & 131.30 \\
\hline & \begin{tabular}{|l} 
JUMLAH HOTSPOT \\
\end{tabular} & 192.00 & 239.00 & 84,00 & 210.00 \\
\hline \multirow{2}{*}{ )товев } & $\begin{array}{l}\text { JUMLAH DEBTT } \\
\left(\mathrm{m}^{3} / \mathrm{s}\right)\end{array}$ & $14,538.20$ & $11,655.72$ & 6,118.94 & $16,609.82$ \\
\hline & \begin{tabular}{|l|l} 
JUMLAH HOTSPOT \\
\end{tabular} & 84.00 & 197.00 & 69.00 & 98.00 \\
\hline \multirow{2}{*}{ NOVEMBER } & JUMLAH & $252,373.47$ & $114,618.78$ & $30,697.36$ & $123,173.15$ \\
\hline & \begin{tabular}{|l}
\multicolumn{1}{|c|}{ JUM HOT } \\
\end{tabular} & 84.00 & 126.00 & 60.00 & 146.00 \\
\hline
\end{tabular}

Tabel 3. Jumlah Debit dan Titik Panas Juni November 2014.

Selain intensitas hujan dan debit limpasan curah hujan, luasan wilayah serta jenis lahan mempengaruhi jumlah titik panas di suatu wilayah. Jenis lahan yang memiliki gambut lebih luas akan membutuhkan banyak air untuk membasahi lahannya. Kelembapan udara di wiliayah tersebut juga mempengaruhi jumlah titik panas di DAS. Hal ini terlihat pada beberapa data harian dimana pada saat debit air limpasan di wilayah tersebut kecil jumlah hotspot bertambah dan pada saat debit air limpasan meningkat jumlah hotspot berkurang.

\section{KESIMPULAN DASN SARAN}

\subsection{Kesimpulan}

1. Jumlah titk panas suatu wilayah berbanding terbalik terhadap debit limpasan dan intensitas curah hujan di suatu wilayah.

2. Jenis lahan dan kondisi kelembapan udara mempengaruhi jumlah titik panas disuatu wilayah.

\subsection{Saran}
1. Ada baiknya data yang digunakan adalah data primer agar tingkat keakuratan data lebih tinggi.

\section{DAFTAR PUSTAKA}

Kertasapoetra, A. G. 2008. Pengaruh Iklim Terhadap Tanah dan Tanaman. Bumi Aksara. Jakarta.

Notohadiprawiro, Tejoyuwono. 1998. Tanah dan Lingkungan. Jakarta: Direktorat Jendral Pendidikan Tinggi Departemen Pendidikan Dan Kebudayaan

http:/hokusai.eorc.jaxa.jp/TRMM/index_e.htm (untuk bulan Juni - November 2014 dengan bentuk data dalam ASCII dengan resolusi $0.1 \times 0.1$ )

https://id.wikipedia.org/wiki/Kabupaten_Ogan_ Komering_Ilir 
